\title{
Title: The dark side of transparency: Does the Nigeria Extractive Industries Transparency Initiative help or hinder accountability and corruption control?
}

\begin{abstract}
This study explores the dark side of transparency by problematizing the Nigeria Extractive Industries Transparency Initiative (NEITI) as a transparency, accountability and anticorruption initiative in Nigeria. It does this by interrogating the underlying assumptions that transparency in the form of increased information disclosure inevitably leads to enhanced accountability and reduced corruption. Theoretic insights are drawn from the transparency literature as well as from the International Accounting Standards Board's framework for financial reporting. The findings enable a more nuanced understanding of transparency where and when transparency works, and where and when it may lead to unintended outcomes. They show how increased information disclosure conceals and legitimises the weak and corrupt reporting systems and practices of government agencies. They highlight the importance of understandability of information disclosed as a key requirement of transparency. They illustrate that transparency is a complex social process by highlighting the means by which the government tries to gain control of the NEITI organisation and how NEITI's ability to operate effectively is dependent on the political will of the government in power. The findings also demonstrate that the instrument through which transparency is enacted is itself a central actor in the transparency process as historical corruption within the NEITI bureaucracy as well as the opacity of NEITI as an organisation lead to outcomes of distrust, uncertainty and doubt amongst NEITIs target audience.
\end{abstract}




\title{
The dark side of transparency: Does the Nigeria Extractive Industries Transparency Initiative help or hinder accountability and corruption control?
}

\author{
"Global EITI is held hostage by Nigeria - how can you criticize \\ Nigeria when it is your flagship project? The Revenue Watch \\ guide for civil society on how to do EITI, written by Glodwyn and \\ Chris Nurse, was overflowing with Nigeria EITI stuff. Peter \\ Eigen said the investment climate in Nigeria has improved \\ dramatically, but the problem is that it is not that golden now. \\ EITI should try not to mention Nigeria so much... it's like they \\ are telling other countries 'you should try and be as transparent \\ as Nigeria'. Is that really such a good idea? - Shaxson (2009 pp \\ 41-42)
}

There is an assumption behind EITI as a whole that if you manage your resources in a more transparent way, that will lead to more accountability and that will lead to better governance and more prosperity for the citizens. The assumptions should be interrogated. The linkages are not automatic.... We should be asking ourselves, despite all we have achieved, how much do the people know about this sector and with what they know are they asking the right questions? - Waziri Adio, Executive Secretary, Nigeria Extractive Industries Transparency Initiative (NEITI) (Channels TV, 2017)

The Extractive Industries Transparency Initiative (EITI) is a multi-stakeholder governance approach that brings together resource-rich developing countries, companies operating in the extractive industries, investor associations and civil society organisations. While the ideas underlying the EITI were outlined in 2002 by Tony Blair, the then Prime Minister of the UK, it was not until June 2003 that some 140 delegates representing 70 governments, companies, industry groups, international organisations, investors and NGOs gathered in London to agree the EITI Statement of Principles (EITI, 2016a). The 12 principles agreed centered on the need for transparency in the management of natural resources. In November 2003, Olusegun Obasanjo, the then Nigerian President, committed to EITI and the Nigeria EITI (NEITI) was launched in February 2004 as a significant part of the transparency and anti-corruption reforms which his government was initiating (NEITI, 2016). Since adopting EITI, Nigeria has made some progress in terms of enhanced information disclosure in the extractive industry and has been held out by the Global EITI as being one of the most successful implementers of the EITI Standard (Eigen, 2006; Haufler, 2010; Shaxson, 2009). 
Underlying the EITI project and its adoption in Nigeria is the assumption that transparency in the form of increased information disclosure by the government and companies in the extractive industries will empower citizens to hold them to account thus improving accountability and reducing corruption (Oge, 2017). A stream of research on EITI has sought to validate this assumption empirically with mixed results. Some studies show that adoption of EITI leads to greater corruption control (Kasekende et al., 2016; David-Barrett and Okamura, 2013) while others refute this link (Sovacool et al., 2016; Oge, 2016; Sovacool and Andrews, 2015; Corrigan, 2014). Studies focused on Nigeria highlight a perception of increased transparency and its role as a tool to drive enhanced accountability and control of corruption (Bature, 2014; Rotimi and Abdul-Azeez, 2013; Ocheni and Nwankwo, 2012).

We take a different and more critical approach to the adoption of EITI in Nigeria by seeking to problematise NEITI as a public sector transparency, accountability and anti-corruption initiative in Nigeria. We 'interrogate' the underlying assumptions that increased information disclosure equates transparency and that transparency in this form can improve accountability and reduce corruption. In doing this we draw on insights from the critical transparency literature (Tsoukas, 1997; Strathern, 2000; Ball, 2009; Meijer, 2013; Fenster, 2005, 2015) as well as from the International Accounting Standards Boards (IASB) Conceptual Framework for Financial Reporting (IASB, 2010).

We show that for information disclosed through NEITI audit reports to be used effectively by its target audience, the information disclosed needs to be timely, understandable and faithfully represent the phenomena which it claims to represent. When the audit reports do not display these characteristics, they are largely ignored by civil society and the public unless they are reminded of the availability of this information and directed on how the information can be used to shape public debate.

Our findings contribute to the transparency and EITI literature (Albu \& Flyverbom, 2016; Bature, 2014; Bushman, Chen, Engel, \& Smith, 2004; Christensen \& Langer, 2009; Eijffinger \& Geraats, 2006; Fenster, 2005, 2015; Meijer, 2014; Öge, 2017; Tsoukas, 1997) in a number of ways. First, we contribute by showing how viewing transparency as increased information disclosure without regard to how the information was produced has led to unintended consequence. This is done by highlighting how increased information disclosure has served as a means of legitimising the weak and corrupt reporting systems and practices of government agencies which provide NEITI with the information on which it bases its audit report. Second, we contribute by highlighting the importance of understandability of information disclosed as a key requirement of transparency. This is done by showing how NEITI audit reports are ignored by their target audience because they are largely unintelligible. Third, we illustrate the complexity of transparency as a social process by highlighting the means by which the government tries to gain control of the NEITI organisation and how NEITI's ability to operate effectively is dependent on the political will of the government in power. Fourth, we contribute by demonstrating that the instrument through which transparency is enacted is itself a central actor in the transparency process. We do this by showing how historical corruption within the NEITI bureaucracy as well as the opacity of NEITI as an organisation lead to outcomes of distrust, uncertainty and doubt amongst NEITIs target audience. These contributions enable a more nuanced understanding of transparency - where and when transparency works, and where and when it may lead to 
unintended outcomes. Indeed, they enable us better understand the darker side of transparency and the links between transparency, accountability and corruption.

The rest of this paper consists of seven major sections. Section 2 sets the scene for the study by providing background information on the Nigerian context, EITIs adoption in Nigeria and NEITI. In Section 3, we develop the theoretical frame for the study by highlighting insights from the transparency literature and the IASB Conceptual Framework for Financial Reporting. Section 4 explains the methodological approach adopted while Section 5 highlights the major findings of the study. The last two sections discuss the findings and make some concluding comments.

\section{Context}

\section{$2.1 \quad$ The Nigerian Context}

Nigeria is the largest oil producer in Africa and was the world's fourth-largest exporter of liquified natural gas in 2015 (US Energy Information Administration, 2016). It accounts for $1.1 \%$ of global gas production and holds $29 \%$ of Africa's proven oil reserves (EITI, 2016b). While Nigeria also has mineral resources such as coal, tin, iron ore, limestone and gold, the mineral sector is largely constituted of artisanal and small-scale mining operations, and most of the major mining projects are at the exploration stage. Thus, the extractive sector is dominated by oil and gas production which accounts for $99 \%$ of extractive sector total revenue (EITI, 2016b).

The oil and gas industries are the mainstay of the Nigerian economy and typically account for about $80 \%$ of total fiscal revenue to the government (public sector revenue), about $90-95 \%$ of export revenue and 30-35\% of GDP (Shaxson, 2009). The most significant revenue streams from the oil and gas industry are petroleum profit tax, royalties and dividends. The Nigerian government participates in the oil and gas industries through the Nigerian National Petroleum Corporation (NNPC), a state-owned corporation, and its various subsidiaries. Oil production in Nigeria is dominated by six Joint Venture arrangements which account for $88.6 \%$ of all oil-specific taxes, the government through the NNPC controls between 55\%-60\% of each of these Joint Ventures.

Despite Nigeria's vast oil wealth and its status as Africa leading oil producer, it is ranked 152 (out of 188 countries) on the United Nations Development Programme's (UNDP) 2016 Human Development Index, falling into the category of 'low human development' (UNDP, 2016). Nigeria was ranked 122 out of 180 countries in the 2017 Press Freedom Index which measures press freedom, an essential component of transparency, (Reporters Without Borders, 2017). Nigeria is ranked 136 out of 174 countries on Transparency International's 2016 Corruption Perception Index (Transparency International, 2017) with a score of 28 out of 100 (where 0 is perceived as 'highly corrupt' and 100 'very clean').

It is against this backdrop that the Nigerian government committed to the EITI Standard in a bid to fight corruption and reverse the resource curse. So, what then is the EITI Standard? 
The EITI is a global standard aimed at instituting good governance in the oil, gas and mineral resources industries. Advocates of the EITI argue that when implemented by a country, it should ensure transparency and accountability regarding how a country's natural resources are governed (World Bank, 2008). Countries intending to implement the EITI standard commit themselves to the 12 EITI principles (see Appendix 1) agreed at the London Conference in 2003 and make a formal application to the EITI. These principles are operationalised through a set of requirements which implementing countries are obliged to adhere to (see Appendix 2). The EITI requirements are considered a minimum threshold and implementing countries are encouraged to go beyond this minimum threshold.

Nigeria was the first country in the world to formally declare its intention to implement the global EITI framework and the Nigeria Extractive Industries Transparency Initiate (NEITI) was officially launched by then President Olusegun Obasanjo in 2004 to implement the global EITI framework (Eigen, 2006). Indeed, Nigeria is considered a flagship in global EITI implementation as the NEITI agenda far surpassed the global EITI standard. Highlighting this in his testimony before the United States Congress, David Goldwyn notes:

"The NEITI process, launched in 2004, is the most comprehensive transparency program ever attempted under EITI auspices ... NEITI set goals far beyond the basic EITI principles of revenue disclosure. Nigerians had little confidence in the integrity of any of the actors in the oil and gas value chain. It was essential to ... examine and audit the quantity of oil and gas lifted from well head to fiscalization, to track the money paid for the oil and gas from first sales to recordation in the Central Bank, to verify that all taxes and royalties and payments of any kind had been paid in full and deposited in the Central Bank, and to examine every major process from licensing to refining. The audits looked deep into the conduct and practices of the Central Bank of Nigeria $(C B N)$, the Department of Petroleum Resources (DPR), the Nigerian National Petroleum Corporation (NNPC), the Federal Inland Revenue Service (FIRS) and many other government agencies." (Goldwyn, 2006)

In setting such a wide remit of conducting not just a financial audit as required by EITI but also conducting physical and process audits, NEITI set itself up as a significant player in the extractive industry regulatory space, a key driver of transparency in the Nigerian extractive industry and a critical part of the Nigerian governments anti-corruption reforms (Shaxson, 2009; Goldwyn, 2006). This position was legitimised and strengthened by the passing in 2007 of the NEITI Act which gave the NEITI organisation legal status and powers. This new status allowed it to develop an organisation structure which includes a secretariat with about 50 staff led by an Executive Secretary and overseen by a National Stakeholder Working Group (NSWG). Appendix 3 outlines major actors in the NEITI process. 
Thus, NEITI's key role is to drive transparency in the Nigerian extractive industry. But, how should we understand transparency? It is to this question we turn in the next section.

\section{$3 \quad$ Theorising Transparency}

Transparency has a long history as a foundational principle for public management and governance (Hood, 2007; Ball, 2009). In the social sciences, it is usually seen as a powerful means towards achieving some desirable social ends like enhancing accountability and reducing corruption (Hansen et al., 2015). However, there is little consensus as to what transparency is with various definitions and conceptualisations of transparency being advanced. Two overarching conceptions of transparency are identified by Albu and Flyverbom (2016) in their review of the transparency literature. The first conceptualisation focuses on the role of information and characterises transparency as the increased disclosure of information. The second conceptualisation of transparency is as a complex communicative, organisational, social process rife with tensions and negotiations. While previous studies have drawn on one or the other conceptualisation of transparency, we draw insights from both conceptualisations in framing our study.

\subsection{Transparency as Information Disclosure}

Popular definitions of transparency define it is as 'lifting the veil of secrecy' (Davis, 1998, pp. 121 ) or 'the ability to look clearly through the window of an institution' (Den Boer, 1998, pp. 105). Here transparency shines light into the darkness, making the invisible visible and 'disinfecting' the state of unaccountability and corruption (Etzioni, 2010). Indeed, transparency is often understood through metaphors like 'sunlight', 'disinfectant' or 'window' (Tsoukas, 1997; Den Boer, 1998; Etzioni, 2010) and construed as the counterpoint to secrecy and opacity.

How then is the veil lifted, or the window opened or the light shone? Several authors, commenting on the 'information society', argue that transparency in this sense is solely dependent on and equivalent to, increased information disclosure (Bushman et al., 2004; Eijffinger and Geraats, 2006; Wehmeier and Raaz, 2012). Indeed, Berglund (2014, pp. 360) notes:

“...transparency will thus require full disclosure of all relevant information in a timely manner"

Underlying this conception of transparency as information disclosure is a linear communication model which posits three things (Fenster, 2015). First, that some actors (usually the state, but in our case, the state and the extractive industry companies) produce information which they control and can be forced to release. Second, the information produced by these actors constitutes a message that can be isolated and disclosed. Third, there is a public waiting for the disclosure of this information which is willing and able to act on it (Fenster, 2005, 2015). This model is illustrated in the definition of transparency by Meijer (2013, pp. 430):

Transparency can be defined as the availability of information about an actor allowing other actors to monitor the workings or performance of this actor. 
This conception of transparency presupposes that the information put in the public domain is useful information and that the public and civil society have the capacity to use this information to monitor the state and corporations (Oge, 2017). Thus, this stream of literature leads us to focus our attention on the capacity of the public and civil society to use the information put in the public domain as well as to ask: is the information put in the public domain by the Nigerian state, extractive industry companies and NEITI useful?

While 'usefulness of information' is presupposed, there is no discussion in the literature as to what it means for information to be useful beyond Berglund's (2014) assertion that information should be relevant, timely and fully disclosed. Consequently, we draw insights from the IASB's Conceptual Framework for Financial Reporting (IASB, 2010) as well as the accounting literature to develop our understanding of what useful information is. The IASB's Conceptual Framework sets out a number of qualitative characteristics which useful information should have. These characteristics include faithful representation, timeliness and understandability.

Faithful representation emphasises the need for the information presented to represent faithfully the phenomena it purports to represent. It implies underlying characteristics of completeness, neutrality and freedom from error. While the conceptual framework emphasises the need for financial information to faithfully represent the underlying reality, the accounting literature shows that in several cases, financial information disclosed is manipulated so as to present a misleading representation to the information users (Rezaee, 2005). Strategies for creating these misleading representations and deceptions in financial statements are identified by Johnson et al. $(2001,1993)$ as: masking $^{1}$, dazzling ${ }^{2}$, decoying ${ }^{3}$, repackaging ${ }^{4}$, mimicking $^{5}$, and double play $^{6}$. An audit serves as a deterrent to these deceptions, misleading representations and fraud (Rezaee, 2005; Wells, 2002). Indeed, Maines and Wahlen (2006) argue that an unqualified audit report is a necessary precondition for users to perceive financial information as reliable and faithfully represented.

Timeliness means that information is available to decision-makers in time to be capable of influencing their decisions and understandability implies that information is presented clearly, concisely and in a manner that makes it understandable to the users. Indeed, Biondi and Lapsley (2014) argue that a higher level of transparency is achieved when there is a genuine level of understanding of the phenomenon disclosed and an even higher transparency level is achieved when a sophisticated level of understanding which extends to shared meanings is held by parties interested in the disclosed phenomenon.

\footnotetext{
${ }^{1}$ Masking occurs when the Deceiver tries to omit or remove attributes of phenomenon being represented

${ }^{2}$ Here the Deceiver tries to diffuse or confuse attributes of the phenomenon being represented which he intends that the user of the information misses.

${ }^{3}$ Decoying is an attempt to focus the information users attention away from the phenomenon being represented.

${ }^{4}$ Here the Deceiver frames or labels the phenomenon being represented in such a way that the user of the information misclassifies it,

${ }^{5}$ the Deceiver modifies the attributes of the phenomenon being represented so that it is mistaken for something else.

${ }^{6}$ Here weak evidence for the correct representation is presented so the information user will dismiss it.
} 
Scholars adopting this understanding of transparency argue that increased disclosure of useful information leads to better governance, improved accountability, reduced corruption and enhanced trust (Hood, 2006; Braithwaite and Drahos, 2000; Finel and Lord, 1999; Wehmeier and Raaz, 2012; Kasekende et al., 2016; David-Barrett and Okamura, 2013).

\subsection{Transparency as a Social Process}

Critical transparency scholars argue that transparency is better understood as a social process which includes components such as the subjects, material objects and settings. Albu and Flyverbom (2016) explain:

"transparency is a process that includes the following components: subjects which are involved in politically motivated interpretations and enactments of transparency... material objects at work in transparency projects that actively mediate and manage its resulting visibilities.... and settings which are the loci of transparency projects...." (Albu and Flyverbom, 2016 pp. 10)

While all of these components are extremely complex and inextricably interwoven, the communication model of transparency provides a useful starting point to analyse the dynamics of the transparency process. This model enables an understanding of transparency as an institutional relationship between the state and the public which can be analysed in terms of rules, interactions, power, context, etc. (Meijer, 2013; Flyverbom et al., 2011). Indeed, Derrida highlights the role that communication plays in establishing complex relations between actors thus:

When I say something to someone, it is not certain that my major preoccupation is to transmit knowledge or meaning; it is rather to enter into a certain type of relation with the other person, to attempt to seduce him or her, or give him or her something, or even to wage war. Thus, beyond the schemas of communication appear other possible finalities. (quoted in Mattelart and Mattelart, 1992, pp. 47)

In such complex processes, conflict and negotiation are inevitable as subjects make decisions on what should be made visible and what should not (Albu, 2014; Thedvall, 2008) and as their cultural and political inclinations clash (Klintman and Bostrom, 2008). The conflicts, negotiations and inevitable compromises in the transparency process highlight the uncertainties, paradoxes and negative consequences which come along with increased disclosure of information. Indeed, Tsoukas (1997) warns:

“...the information society is a society full of temptations: it tempts us into thinking that our modern desires of transparency and societal regulation will be realized through greater knowledge. But not any kind of knowledge will do; only knowledge conceived as information...is seen as useful. This tantalizing dream, however, ...is bound to remain unfulfilled. Like Tantalus, the members of the information society, much as they desire it, will not be able to taste the fruits of higher transparency: society will remain as opaque as it has always been and, in some ways, it will become more unfathomable as well as unmanageable. The information society spawns paradoxes that prevent 
it from satisfying the temptations it creates. The light that the information society promises to direct upon itself may well constitute a new tyranny: the tyranny of radical doubt, of disorientation, and of heightened uncertainty.

Exploring the unintended consequences of increased information disclosure, Strathern (2000) argues that by shining light on certain issues, by making them visible, we conceal other issues in darkness. She argues that the question to researchers should then become 'what does visibility conceal?' (Strathern, 2000 pp. 310). Other unintended consequences include the undermining of trust (Tsoukas, 1997; Eisenberg, 2007), growing uncertainty or suspicion visa'-vis institutions and the people working in them (Strathern, 2000) and the emergence of new types of closure, self-censorship and anxiety (Christensen and Langer, 2009). Insights from this stream of literature lead us to ask: 'what does visibility conceal i.e. What does the information disclosed by the Nigerian state, extractive industry companies and NEITI conceal?'; 'what are the institutional relations which shape information disclosure and the use of disclosed information?' and 'what are the unintended consequences of putting information in the public domain by the state, extractive industry companies and NEITI?'

From the foregone we come to the following conclusions:

i. Transparency entails shining light on objects and making them visible. However, in making the invisible visible, it conceals other things.

ii. Transparency can be viewed as a process and as comprising institutional relations which can be analysed in terms of subjects, setting, rules, interactions, power, etc.

iii. Transparency is seen as information disclosure. However, the information disclosed has to be useful and the public and civil society have to be able to use the information disclosed.

iv. Transparency can have unintended consequences.

Methods

We set out to problematize NEITI as a transparency and anti-corruption initiative in Nigeria by challenging the underlying assumption of transparency as information disclosure and its link with accountability and corruption in Nigeria. Following the methodological traditions of sociohistorical research (Brivati et al., 1996) as well as critical accounting research (McPhail et al., 2016; Sikka and Willmott, 2010; Haynes, 2010) we draw on a range of data sources which include NEITI audit reports, documents relating to the development and implementation of the global EITI framework, NEITI press releases and communications, all NEITI documents publicly available on their website, Chatham House and other civil society reports on NEITI, media reports on NEITI and the Nigerian extractive industry, KPMG and PricewaterhouseCoopers forensic investigation reports on NNPC and US Embassy in Nigeria cable communication obtained from WikiLeaks. We also draw on audio and written transcripts of legislative hearings and proceedings related to NEITI as well as video recordings of press interviews given by NEITI officials. We had also sought to obtain interviews from NEITI officials and board members. However, our requests were declined with the NEITI officials and board members citing confidentiality agreements which prevented them from granting interviews. Appendices 4 and 5 give details of data sources. 
The data collected was analysed qualitatively with the aim of understanding the workings of NEITI as a transparency and anti-corruption initiative. Figure 1 sets out the analytic process engaged in by the research team.

Figure 1: $\quad$ The Analytic Process

\section{Xxxxx insert figure 1 here $\mathrm{xxxxx}$}

We began our analysis by familiarising ourselves with the data. This was done through an iterative cycle of reviewing the data, reflecting and re-reviewing the data. As we reviewed the data iteratively, we were constantly asking ourselves 'what is going on here?'; 'how useful is the information disclosed?'; 'what does increased information disclosure conceal?'; what are the institutional relations which shape information disclosure and the use of disclosed information' and 'what are the unintended consequences of transparency?'. This helped us develop a stream of reflective notes. We then started to sift the data, collating whatever seemed important and discarding the irrelevant. Our approach to the data was sensitised by our understanding of the theoretic concept of transparency detailed in the previous section. Thus, our understanding of the concept informed our approach to the data, directed us to areas of interest while not constraining out ability to develop novel insights (Anderson et al., 2010).

The next phase of our analysis was a search for patterns in the data. In searching for patterns, we employed the constant comparative method of analysis (Jack et al., 2010; Jack and Anderson 2002; Anderson and Jack, 2002). In this method, analysis is achieved through two main activities: fragmentation and comparison (Boeije, 2002). In our case, fragmentation was achieved through the open coding of individual documents. This allowed us to lift pieces of coded data out of the context of the whole document for comparison. Codes were then compared at different levels e.g. within documents, between documents, within emergent categories and themes, between emergent categories and themes. Through this process of fragmentation and constant comparison, themes and categories started to emerge and be refined. Fragmentation and comparison also enabled us to triangulate data from the various sources. This enabled us gain a measure of confidence that the themes which emerged, and the interpretations developed subsequently, were well grounded in the data. The final stage involved a synthesis of the descriptive categories into analytic categories which give insight into the research question and enable the development of an explanatory frame. To do this we moved abductively between our empirical findings, theoretic concepts and the developing explanatory frame in a reflective spiral. This allowed our sensemaking of our empirical results to be informed by theory while giving us the opportunity to develop new insights. Thus, over several iterations, elements of the explanatory frame were retained, revised, removed or added. The findings and explanatory frame developed are presented in the next section.

\section{$5 \quad$ Findings}

\subsection{Usefulness of disclosed information}

In assessing the usefulness of the information disclosed, we draw on insights from the IASB Conceptual Framework for Financial Reporting which highlights timeliness, 
understandability and faithful representation as qualitative characteristics of useful information (IASB, 2010).

\subsubsection{Timeliness}

Timeliness means having information available to users in time to be capable of influencing their decisions. Generally, the older the information is the less useful it is. While it is usual to have audit reports on an annual basis for corporations in the private and public sector, the EITI Standard allows for reports to be lagged for two years. This makes the reports less effective as they are less contemporaneous with events in the industry which move very fast. In addition to this, NEITIs reporting practice highlighted in Table 1 below indicates a time lag of between 2 and 5 years with only the 2013, 2014 and 2015 audit reports being produced within the EITI two year timeframe.

Table 1: $\quad$ NEITI Reporting Practice

Xxxxx Insert Table 1 here $\operatorname{xxxxxxxx}$

Explaining the reasons for the delayed production of NEITI audit reports, its Executive Secretary comments:

"It could be better because the more recent the reports are the more effective, the more impactful they will be..... the process of procuring the auditors takes a lot of time, the process of getting the public funding to pay for the auditors also takes a lot of time" (Channels TV Interview A)

Thus, while there is a recognition of the institutional factors and relations which NEITI needs to negotiate in order to produce its reports in a timely manner, there is also a recognition that reports need to be produced in a timely manner in order to be 'effective' and 'impactful' as the older the information, the less useful it is in driving accountability within the extractive industry.

\subsubsection{Understandability}

Both the IASB Conceptual Framework and the EITI Standard identify understandability to its target audience as a key characteristic of useful information. The EITI identifies its target audience as:

"government, parliamentarians, civil society, companies and the media” (EITI Guidance Note 12)

This target audience comprises a wide range of individuals and groups with varying skills and abilities. However, the NEITI reports are usually in highly technical language and are quite lengthy - most well between 100 and 400 pages long not including Appendices. The former Executive Secretary of NEITI comments on this:

"In order to meet required international standards, the NEITI audit reports are usually presented in forms that are hardly digestible by majority of the target audience. They contain complex accounting 
jargons that would make little or no meaning to non-accountants. NEITI undertakes the task of simplifying the audits but the best of these simplified versions do not make great difference because of the need to avoid the risk of misinterpreting the original contents of the audits." (Presentation by NEITI Executive Secretary to IMF Mission on 21 March 2012)

With the legislators, civil society and the public hardly able to understand the NEITI audit reports without the aid of specialist advisors, it comes as no surprise that these reports were largely ignored until scandals within the Nigerian oil industry brought them to light well over ten years after NEITI started producing these reports. This is highlighted in the former NEITI Chairman's comments:

"....issues of corruption revealed in the fuel subsidy probe by the National Assembly was the first time that Nigerians were made aware of the presence of huge reports that have been in the public domain already about the issues in the nation's petroleum industry, which was produced by NEITI over the years." (Onwuemenyi, 2012)

Thus, as a result of the incomprehensibility of the NEITI audit reports to the majority of its audience, although in the public domain, they were not used by the public in driving accountability. It was a later scandal that brought issues on which NEITI reported to the fore of public debate and then NEITI officers highlighted the potential use their reports could be put to.

\subsubsection{Faithful Representation}

The IASB Conceptual Framework identifies faithful representation as a fundamental characteristic of useful information. It notes:

"To be useful, financial information must not only represent relevant phenomena, but it must also faithfully represent the phenomena that it purports to represent ..... To be a perfectly faithful representation, a depiction would have three characteristics. It would be complete, neutral and free from error.... A complete depiction includes all information necessary for a user to understand the phenomenon being depicted, including all necessary descriptions and explanations." (IASB, 2010 pp. 13)

A careful reading of the NEITI audit reports highlights several issues where phenomena are not represented faithfully. While there are several issues which we could use as illustrations, for brevity, we illustrate with the issue of oil theft reported within the NEITI audit reports.

The 2016 NEITI oil and gas audit report states:

"Crude oil losses is often associated with activities relating to the theft or sabotage of crude oil, facilities or installations in form of illegal bunkering, pipeline vandalism, fuel scooping, illegal refining and transport and oil terrorism.....Nigeria currently loses about \$4 million 
daily to crude oil thieves" (NEITI 2016 oil and gas audit report, pp.220)

The report goes on to give nine pages of precise data quantifying the amount of oil lost to theft as reported by the oil companies. While the audit report purports to give a comprehensive account of crude oil theft, in reality, it only accounts for theft of oil which occurs at the oil terminals and any subsequent point. Other aspects of oil theft are ignored by the audit reports creating an impression that this aspect of oil theft is immaterial and irrelevant. However, this is not the case. The US Consul General (ConGen) in Lagos highlights these other aspects of oil theft and their significance in the Nigerian context:

"Oil can also be stolen without disruption to the legitimate flow of oil from the well-head to the tank farm and without the use of force - much less the messy business of "bunkering" the oil in the creeks. Such thefts occur when individuals fail to register portions of the oil delivered to and stored at official tank farms on the official accounts of the Nigerian National Petroleum Corporation and, instead, sell such oil "under the counter" or "off book" for the account of one or more beneficiaries. Different contacts on various occasions told ConGen personnel that this method accounts for the largest volume of oil stolen in Nigeria and that the beneficiaries of this "creative accounting" involve people "very close to the presidency." "(US Embassy Cables Leak, Wikileaks Cable 09LAGOS438_a)

NEITI is well aware of this fact as this point is noted in discussions and comments outside the audit report. Indeed, the document produced on NEITI staff reflections on 10 years of NEITI audit reports notes that:

"The actual amount of oil produced in Nigeria is not known. Oil is measured at terminals but not at well-heads of flow stations. Around $10 \%$ of oil is estimated to be lost or stolen between these points" (NEITI Report, 2010)

The non-inclusion of this aspect of oil theft in the NEITI audit reports, given its significance and NEITI's knowledge of its scope and significance, signals a departure from the principle that the information reported should be a faithful representation of the phenomenon which it claims to represent. Indeed, by unfaithfully representing oil theft and concealing a significant aspect of oil theft, NEITI helps to entrench the corrupt system which enables this theft to occur unnoticed and unreported.

\subsection{What does visibility conceal?}

NEITI seeks to promote transparency by making information which had previously been circulated amongst a small group in government and industry public and accessible. It does this by ensuring compliance with the EITI principles and requirements which compel the disclosure of information through NEITI audit reports. While these audit reports reveal a lot, we are interested in what they conceal. We find that one of the key things which the audit 
reports conceal is the reliability of the systems and structures which generate the information disclosed. The NEITI reports are based on data produced by the Nigerian public sector institutions and agencies (NNPC, DPR, Ministry of Finance, and Central Bank of Nigeria) as well as companies operating in the sector. This follows the approach recommended by the EITI Standard:

"the standard .... encourages countries to build on their existing
reporting systems and practices for EITI data collection, rather than
burdening themselves by duplicating the process through EITI
reporting. I am confident that this will make EITI data more timely,
reliable and accessible, and the EITI process more cost effective and
efficient" (EITI, 2016c)

While the idea of piggy-backing on existing data collection and reporting systems and practices sounds like a good and cost effective one, it does not consider the social context in which these information collection and reporting systems are embedded. Indeed, in a country like Nigeria which has seen several decades of corruption, these systems are largely nonexistent and where they do exist they are so deeply rooted in the corrupt system that the data collected and the reports produced from this information is at best unreliable. The weakness of existing public sector accounting and reporting systems is highlighted by a PricewaterhouseCoopers $(\mathrm{PwC})$ report of their forensic audit of NNPCs remittances into the Nigerian governments account thus:

"...the accounting and reconciliation system for crude oil revenue used by Government agencies appear to be inaccurate and weak....." $(P w C$, 2015 pp. 18)

Indeed, the weakness of the accounting and reporting systems of public sector agencies is well known and has been documented severally. An insider in the Nigerian oil industry commenting on this notes:

"there was simply no tradition of good record-keeping. As one insider put it, 'The Central Government did not keep records on a computer. The tax authorities didn't audit taxes. The royalty authorities didn't audit royalties.' There were major problems too at the Central Bank and the Accountant-General's office, both of which did not keep good records. " (quoted in Shaxson, 2009 pp. 28)

Beyond the systemic weaknesses is the system of 'creative accounting' noted in the discussion on oil theft above which has permeated the accounting and reporting systems of NNPC and other public sector agencies in the extractive industry.

The inaccuracy and weakness of the accounts and reports which NEITI draws on in developing its audit reports is not acknowledged in the NEITI reports which instead claim to be based on the assumption that:

"The data and/or information to be received from the covered entities are genuine and consistent" (NEITI 2013 Oil and Gas Audit Report, pp. 17). 
By ignoring the context in which the information underpinning the NEITI audit reports is generated and reported, NEITI has ended up in a position where the information used in its audit reports is at best unreliable. Publishing of this unreliable information through the NEITI reports serves to legitimise the system which produced it. As such, while NEITI has brought about transparency in the narrow sense of 'information disclosure', it has served to conceal, legitimise and entrench the corrupt systems and reinforce the lack of accountability in the system.

\subsection{The transparency process}

We find that the NEITI transparency process is impacted on by a range of factors which include the political will of the government in power, the involvement of civil society in the process and opacity of NEITI as an institution.

\subsubsection{Political will of the government in power}

NEITI was introduced into the Nigerian regulatory space as part of the anti-corruption reform of the then president Olusegun Obasanjo. Shaxson (2009) in his study of NEITI finds that the primary motivator for its introduction was the need to enhance the countries international reputation thus enabling the government to achieve its debt restructuring deal with the International Monetary Fund (IMF) and other international creditors (Asgill, 2012). At the time, NEITI was given all the support it needed to function effectively. However, once debt restructuring was achieved, the reforms began to falter and NEITI and its audit reports were relegated to the sidelines (Muller, 2011). Two subsequent governments led by President Yaradua and President Johnathan did not back the anti-corruption reforms and so NEITI did not achieve much during their tenures. However, the current President, Muhammadu Buhari has sought to reintroduce anti-corruption reforms and has empowered NEITI to act on its mandate. The NEITI Executive Secretary responding to a question in a media interview on how much influence the government wields on NEITI, comments:

"a lot..... A lot in the sense that everything rises and falls on political
will. If you do your reports and you make tons of recommendations, and
the government does not have the appetite to push through or does not
have the will to push through, then you are just doing your audit
report.... Political will is very critical ...... what of if the government
is not interested in transparency, what of if the government is not
interested in reforms.... Political will is not a given, it is not something
that any government owes anybody". (Channels TV Interview B)

Indeed, the absence of political will is not just characterised by the lack of willingness to follow through on audit recommendations but an active protection of the corrupt individuals and organisations which empowers them to challenge the NEITI audit reports even when they know that their challenge is unfounded. This is highlighted by the NEITI Executive Secretary's comment to the press on the NNPCs response to the most recent audit report published during President Buhari's tenure:

"If you notice this year, NNPC or its subsidiaries have not come out to say, all those allegations you are making, they are wrong, because they 
know that they do not have the protection. If NNPC operated the way they operated in the past, it is because it served the interests of some people for it to be so and there was an institutional cover for what they did ..." (News Agency of Nigeria TV Interview)

Thus, the political will of the government in power is a key mediator of the impact which the NEITI transparency process has both in terms of the acceptance of NEITIs reports and the use to which the reports are put. Indeed, the ability of NEITI audit reports to drive change in agencies like NNPC in terms of increased accountability and reduced corruption depends on how much 'protection' these government agencies receive from the government in power.

\subsubsection{Constitution and independence of the NSWG}

The NSWG is the board of NEITI which is responsible for the formulation of its policies, programmes and strategies. Section 6 of the NEITI Act provides that the President shall have the power to appoint and remove the members of the NSWG who shall consist of a Chairman, the NEITI Executive Secretary, one representative from civil society, one representative from the labour unions in the extractive industry, one representative of extractive industries companies, experts in the extractive industry and one representative from each of the countries six geo-political zones. While the Act stipulates the constituencies from which the members of the NSWG should be drawn, it does not stipulate how they are chosen. This leave the President with absolute discretion to choose representatives based on political as opposed to technical considerations.

Even if the representatives from the extractive industry companies, civil society and labour unions were nominated by their constituencies, they make up only three out of the 15 members of the NSWG. Indeed, the practice by the government has been to appoint NSWG members who have significant ties to the government or the ruling political party. This was highlighted by a civil society leader commenting on the dissolution of the NSWG by the Buhari government when it came into office:

"most members of the dissolved NEITI Board were card-carrying
members of the Peoples Democratic Party (PDP), with little or no
interest on EITI/NEITI ... the dissolution was a relief to most Nigerians,
as the Board not only lost its independence, neutrality and moral right,
but also lacked the trust to perform its role... with the outcome of the
March 28, 2015 elections in which the PDP was defeated, the popular
expectation was that most members of the Board would have resigned,
in view of their open partisanship, particularly against the issue of total
overhaul and reforms in the oil sector. (Udo, 2015)

While a lot of hope was held out for the appointment of a new and independent NSWG by the Buhari government, it in fact went further than previous governments in trying to bring the NSWG under its control. It appointed the government minister for solid minerals as the NEITI Chair, a position usually held by a civil society activist and it sought to appoint the civil society representative without consulting with civil society organisations. The composition and lack of independence of the NSWG have fuelled the perception of the NSWG having nothing at stake in the fight against corruption with a civil society activist noting: 
"NEITI is a government agency and if you are a government agency in Nigeria, you must dance to the tune of the government" (civil society activist quoted in Abutudu and Garuba, 2010 pp.52)

This domination of the NSWG by the government has led to a distrust of both the government and the NSWG by civil society as illustrated by their rejection of the civil society representative on the NSWG appointed by the government:

"We wish to state that we find the announcement disruptive, prejudicial to the on-going process and in bad faith. It is pertinent to ask at this juncture: When did the process that produced Kola Banwo as CSO representative begin and end? What procedure did it follow? Which CSOs participated in that process? Did it reflect the EITI's principle of transparency? Does the appointment of Kola Banwo meet the provisions of the EITI Standard and more specifically, its CSO Protocol? ....... We therefore wish to state that the surreptitious character of this announcement of Banwo as CSO representative makes a mockery of the EITI Principles and flies in the face of the intrinsic values of the constituency he seeks to represent." (statement by coalition of civil society organisations quoted in Olayinka, 2016)

In addition, the NSWGs lack of independence raises questions about the ability of NEITI to function effectively as an instrument of transparency as it is the NSWG which determines the scope, quality and timing of audit reports.

\subsubsection{The touch-bearer - NEITI as an institution}

While the literature which views transparency as a light shining in the darkness focuses on the opacity of an actor (state and corporations) and the light (information disclosure) which dispels the darkness, no attention is paid to the instruments by which the light is shone. In our case, directing the light at the instrument of transparency (NEITI) produces some interesting results.

\subsubsection{Corruption within NEITI}

The NEITI Secretariat has six departments with about 50 staff and is headed by the NEITI Executive Secretary. When the secretariat was set up initially, its staff was mostly made up of civil servants who were deployed to NEITI from other ministries. Commenting on this, Muller (2011, pp. 80) notes that:

"mostly, the deployment is actually based on politics, nepotism, favouritism and all of that"

Given the corrupt nature of deployment of staff to NEITI, it was not long before allegations of financial corruption within the NEITI bureaucracy began to surface. In 2010 allegations surfaced that the NEITI Director of Services was accused of over-invoicing and making unauthorised payments to hotels in respect of a NEITI organised civil society training programme to the tune of $\$ 100,000$ (Udo, 2010). The matter was referred to the NEITI board and disciplinary action was taken against the Director. Also, a commitment was made to restructure the NEITI secretariat. A few months later, the Executive Secretary was accused of corruption and abuse of office in a series of petitions and public letters to the President. $\mathrm{He}$ 
was replaced by the President before investigations into these allegations could take place (Goxi, 2010). Whether true or false, the allegations of corruption within NEITI damaged the organisations reputation both locally and internationally. The Revenue Watch Institute's Nigeria representative noted at a book launch on NEITI:

"I have been engaged with EITI issues with my New York office in the past two weeks .... At every point, the development in the NEITI

Secretariat keeps recurring. As a global initiative that Nigeria convincingly led since inception, it is a pity to know of the allegations of corruption within NEITI Secretariat. This is particularly intriguing because it touches the very reasons for which NEITI was set up." (Speech by Dauda Garuba)

While the NEITI board claims to have reorganised the Secretariat after these incidents, the stigma and distrust arising from them still linger (Abutudu and Garuba, 2010).

\subsubsection{Opacity of NEITI}

The Global EITI as part of the EITI Standard has developed an EITI openness policy which sets out how EITI itself should be transparent. While this policy states that documents of EITI are public and should be accessible to the public, it exempts internal documents from the access. However, it goes on to state that EITI board minutes, as well as committee and working group minutes, are not regarded as internal documents.

Although the Global EITI has complied with this openness policy by publishing minutes of its board, committee and working group meetings, in Nigeria, NEITI has not published minutes of any board, committee or working groups. In addition to not publishing minutes, it shrouds its operations in secrecy by placing limits on the ability of staff and board members to discuss the operations of the organisation with outsiders. Indeed, current and previous board members refused to grant our research team interviews citing confidentiality agreements entered into with NEITI.

Thus, while 'lifting the veil' in the extractive industry, NEITI as an organisation had developed its own forms of closures to ensure that its own curtains remain shut to outsiders. This closure, coupled with the effect of the corruption allegations on its reputation serve to create doubt, uncertainty and mistrust in the minds of NEITI's target audience and partners.

\section{Discussion}

At the end of Section 3 we concluded that:

i. Transparency entails shining light on objects and making them visible. However, in making the invisible visible, it conceals other things.

ii. Transparency can be viewed as a process and as comprising institutional relations which can be analysed in terms of subjects, setting, rules, interactions, power, etc.

iii. Transparency is seen as information disclosure. However, the information disclosed has to be useful and the public and civil society have to be able to use the information disclosed. 
iv. Transparency can have unintended consequences.

Based on this understanding of transparency, we set out to problematize NEITI as a public sector transparency and anti-corruption initiative in Nigeria by 'interrogating' its underlying assumptions that transparency in the form of increased information disclosure leads to enhanced accountability and reduced corruption. Figures 2 provides a visual representation of our findings:

Figure 2: $\quad$ NEITI Transparency Process

Xxxxx Insert Figure 2 here $x x x x x x x x x$

We show that while EITI adoption in Nigeria and NEITI have driven increased information disclosure by both the government and companies operating in the extractive industry, increased information disclosure through the NEITI audit reports has not led to enhanced accountability and a reduction in corruption as envisaged by EITI and NEITI. Quite to the contrary, increased information disclosure through NEITI audit reports has had the unintended consequences of entrenching inefficient and corrupt systems, creating distrust between civil society organisations and the government as well as permitting unaccountability in the extractive industry. These unintended consequences result from the complex social dynamic of the NEITI process where NEITI far from being a neutral actor is controlled by the government in power whose will to enact reform also determines the behavioural impact NEITI audit reports have on actors in the extractive industry. The centrality of NEITI as an organisation in this social process is highlighted as civil society's perception of government control of the NEITI organisation, its reputation for internal corruption as well as its opacity as an organisation are significant factors in the trust relationship between civil society and NEITI. These coupled with the incomprehensibility of the audit reports to most of the NEITI target audience, lateness in publishing audit reports as well as the audit reports unfaithful representation of information, have resulted in the limited use of NEITI audit reports in holding actors in the extractive industry to account. Thus, NEITI far from being a solution to the problem of accountability and corruption in Nigeria has become part of the problem. Indeed, while research on EITI and NEITI has emphasised their institutionalisation and efficacy as a solution to corruption, we present an alternative and more critical perspective of these transparency bodies and their relationship with accountability and corruption. We encourage future researchers to adopt similar critical perspective in investigating EITI and NEITI.

Beyond the problematisation of NEITI, our findings contribute to the theoretic understanding of transparency as they present a more nuanced view of transparency both as information disclosure and as a process. In relation to the narrow view of transparency as information disclosure (Bushman et al., 2004; Eijffinger and Geraats, 2006; Wehmeier and Raaz, 2012; Berglund, 2014), they reinforce the arguments in the literature that transparency in this form requires a full and timely disclosure of all relevant information (Berglund, 2014). In addition, they show that the usefulness of the information disclosed is linked strongly to the understandability of the information by its target audience. Thus, we argue that an additional requirement of transparency as information disclosure is the understandability of information disclosed. In relation to transparency as a process (Meijer, 2013; Flyverbom et al., 2011; Abu 
and Flyverbom, 2016; Albu, 2014; Thedvall, 2008), our findings emphasise the view in the literature of transparency as a complex social process which sometimes has unintended consequences (Tsoukas, 1997; Strathern, 2000; Eisenberg, 2007; Christensen and Langer, 2009). However, they go on to extend the view in the literature of transparency as involving 'actors' and 'light' by highlighting the central role which the instrument by which light is shone plays in the transparency process. Indeed, we show that no matter how bright the light shone, it is the hand carrying the light which directs its beams and which actors need to trust as being neutral and itself accountable, free from opacity and corruption. Thus, as in our case with NEITI, where an organisation is the instrument through which transparency is enacted, that organisation itself has to be transparent and seen to be so.

In addition to contributing to the theoretic understanding of transparency, our findings have implications for policy and policy development. Our findings have shown that the Nigerian context has influenced the manner in which the EITI was implemented in Nigeria. This has led to consequences not intended by the EITI. The lesson here relates to the development of global policies intended for implementation locally. In designing such policies, consideration has to be given to how these will be shaped by local contexts and provisions have to be made which enable these policies to adapt to the local context without losing their efficacy. In our case, concrete suggestions to limit the manner in which the local context influences the implementation of the EITI include: amending the EITI policies to allow the local implementing agency more flexibility in its methods relating to data collection; the EITI framework being amended to guarantee greater independence of the local implementing agency from the government in terms of control over funding, governance and operational activities; and requiring adopting governments to strengthen the local implementing agency's powers to follow up on audit findings.

Also important are the implications of our findings for practice. Our findings highlight the importance of transparency and accountability within the implementing agency (NEITI). While the policy framework which should ensure this transparency exists, NEITI does not adhere to these policies. To ensure that these policies are adhered to, internal governance of NEITI needs to be strengthened and the EITI needs to either ensure greater control over NEITI operations or exert significant and sustained pressure on NEITI to ensure compliance. Indeed, these findings in terms of internal transparency and accountability are also relevant to Supreme Audit Institutions.

7

\section{Conclusion}

"that more knowledge could cause problems, that light might prove another tyranny, that knowledge might bring suffering, were not thoughts the philosophers of the Enlightenment were prepared to entertain". (Tsoukas, 1997, pp. 839)

We set out to problematise NEITI as a transparency, accountability and anti-corruption initiative by 'interrogating' its underlying assumptions that transparency in the form of increased information disclosure leads to enhanced accountability and reduced corruption. To do this, we drew on insights from the transparency literature which view transparency both as information disclosure underpinned by a linear communication model and as a social process. 
We also drew on insights from the IASB Conceptual Framework for Financial Reporting in developing our understanding of what useful information is.

In studies such as this, it is customary to acknowledge and reflect on the limitations of the study. Chief amongst the limitations was the paucity of primary data. This was the case as several members of civil society, staff of government agencies as well as NEITI staff and board members (past and present) refused to grant interviews to the research team.

Consequently, we conducted the study by drawing on a wide range sources which included media articles and reports, civil society reports, NEITI press releases as well as media interviews, presentations and testimony before the legislative house by civil society actors, NEITI staff and board members. This enabled us to gather a rich pool of data on which the study is based.

In spite of the limitations, our study makes significant contributions to the transparency and EITI literature in a number of ways. First, we highlight how the accountability function of NEITI has been eroded as the global EITI was translated to fit in with local systems and cultures and how indeed it has moved from being a solution to the problems of transparency, accountability and corruption in Nigeria to being part of the problem. Second, we show the unintended consequences of adopting a view of transparency as information disclosure without regard to how the information was produced. We did this by highlighting how increased information disclosure through NEITI audit reports legitimised the weak and corrupt reporting systems and practices of government agencies which provide NEITI with the information on which it bases its audit report. Third, we draw attention to the importance of understandability of information disclosed as a key requirement of transparency by showing how audit reports are ignored by the public because they are largely unintelligible. We also illustrate the complexity of transparency as a social process by highlighting the power struggles for the control of the NEITI organisation and how NEITI's ability to operate effectively is dependent on the political will of the government in power. Finally, we underscore the importance of the instrument through which transparency is enacted as a central actor in the transparency process. We do this by illustrating how historical corruption within the NEITI bureaucracy as well as the opacity of NEITI as an organisation lead to outcomes of distrust, uncertainty and doubt amongst NEITIs target audience. These contributions enable a more nuanced understanding of transparency - where and when transparency works, and where and when it may lead to unintended outcomes. Indeed, they enable us better understand the darker side of transparency and the links between transparency, accountability and corruption.

We hope that our study opens up a space within the accounting and public administration fields to more actively 'interrogate' the assumptions which underpin the EITI and its adoption in resource rich countries. Of particular importance is the need for future research to investigate the process through which the EITI is implemented and the effect the local context has on EITI adoption and implementation. This should enable a better understanding of what transparency is and the conditions under which EITI adoption can lead to increased transparency, accountability and reduced corruption. 


\section{Appendix 1 - EITI principles (EITI 2016c)}

1. We share a belief that the prudent use of natural resource wealth should be an important engine for sustainable economic growth that contributes to sustainable development and poverty reduction, but if not managed properly, can create negative economic and social impacts.

2. We affirm that management of natural resource wealth for the benefit of a country's citizens is in the domain of sovereign governments to be exercised in the interest of their national development.

3. We recognise that the benefits of resource extraction occur as revenue streams over many years and can be highly price dependent.

4. We recognise that a public understanding of government revenues and expenditure over time could help public debate and inform choice of appropriate and realistic options for sustainable development.

5. We underline the importance of transparency by governments and companies in the extractive industries and the need to enhance public financial management and accountability.

6. We recognise that achievement of greater transparency must be set in the context of respect for contracts and laws.

7. We recognise the enhanced environment for domestic and foreign direct investment that financial transparency may bring.

8. We believe in the principle and practice of accountability by government to all citizens for the stewardship of revenue streams and public expenditure.

9. We are committed to encouraging high standards of transparency and accountability in public life, government operations and in business.

10. We believe that a broadly consistent and workable approach to the disclosure of payments and revenues is required, which is simple to undertake and to use.

11. We believe that payments' disclosure in a given country should involve all extractive industry companies operating in that country. 
12. In seeking solutions, we believe that all stakeholders have important and relevant contributions to make - including governments and their agencies, extractive industry companies, service companies, multilateral organisations, financial organisations, investors and non-governmental organisations 


\section{Appendix 2 - EITI requirements (EITI, 2006c)}

i. Oversight by an effective multi-stakeholder group which involves the government, companies, and the full, independent, active and effective participation of civil society

ii. Full disclosure of information relating to the legal and institutional framework which regulates the extractive industry including the allocation of contracts and licences

iii. Full disclosure relating to exploration and production of oil, gas and mineral resources

iv. Full disclosure of company payments and government revenue from the extractive industries. These are required to be independently reconciled

v. Full disclosures of information related to revenue allocations, enabling stakeholders to understand how revenues are recorded in the national and where applicable, subnational budgets

vi. Full disclosures of information related to social expenditures and the impact of the extractive sector on the economy

vii. Ensuring outcomes and impact

viii. Compliance with deadlines. 
Appendix 3 - List of actors referred to and their relationship with NEITI Xxx insert table 2 here $\mathrm{xxxx}$ 
Appendix 4 - Data sources referred to in the text

Xxxxx Insert Table 3 here $x x x x x x x$ 
Appendix 5 - Other data sources

Xxxx Insert Table 4 here xxxxx 


\section{References}

Abutudu, M., \& Garuba, D. (2010). natural resource Governance and eiti implementation in nigeria. Nordiska Afrikainstitutet.

Albu, O. B. (2014). Transparency in organizing: A performative approach. Copenhagen: Copenhagen Business School.

Albu, O. B., \& Flyverbom, M. (2016). Organizational Transparency. Business \& Society, 0007650316659851.

Anderson, A. R., Dodd, S. D., \& Jack, S. (2010). Network practices and entrepreneurial growth. Scandinavian Journal of Management, 26(2), 121-133.

Anderson, A. R., \& Jack, S. L. (2002). The articulation of social capital in entrepreneurial networks: a glue or a lubricant? Entrepreneurship \& Regional Development, 14(3), 193-210.

Asgill, S. (2012). The Nigerian extractive industries transparency initiative (NEITI): Tool for conflict resolution in the Niger delta or arena of contested politics? Critical African Studies, 4(7), 4-57.

Ball, C. (2009). What is transparency? Public Integrity, 11(4), 293-308.

Bature, B. (2014). Transparency and Accountability: Adaptation and Implementation of Extractive Industries Transparency Initiative (EITI) Principles in Nigeria. The Macrotheme Review 3 (8), 107, 114.

Berglund, T. (2014). Corporate Governance and Optimal Transparency. In J. Forssbaeck \& L. Oxelheim (Eds.), The Oxford Handbook of Economic and Institutional Transparency (pp. 359-70). Oxford: Oxford University Press.

Biondi, L., \& Lapsley, I. (2014). Accounting, transparency and governance: the heritage assets problem. Qualitative Research in Accounting \& Management, 11(2), 146-164.

Boeije, H. (2002). A purposeful approach to the constant comparative method in the analysis of qualitative interviews. Quality \& Quantity, 36(4), 391-409.

Braithwaite, J., \& Drahos, P. (2000). Global business regulation. Cambridge: Cambridge university press.

Brivati, B., Buxton, J., \& Seldon, A. (1996). The contemporary history handbook.

Manchester: Manchester University Press.

Bushman, R., Chen, Q., Engel, E., \& Smith, A. (2004). Financial accounting information, organizational complexity and corporate governance systems. Journal of Accounting and Economics, 37(2), 167-201.

Channels Television. (2017). Hard Copy: More Still Need To Be Done On Transparency In The Extractive Industry - Waziri Adio. Retrieved from https://www.youtube.com/watch?v=jTeGktXZpak 
Christensen, L. T., \& Langer, R. (2009). Public relations and the strategic use of transparency: consistency, hypocrisy and corporate change. In R. L. Heath, E. Toth, \& D. Waymer (Eds.), Rhetorical and critical approaches to public relations II (pp. 129-153). Hillsdale, NJ: Lawrence Erlbaum.

Corrigan, C. C. (2014). Breaking the resource curse: Transparency in the natural resource sector and the extractive industries transparency initiative. Resources Policy, 40, 17-30.

Cressey, D. R. (1953). Other people's money; a study of the social psychology of embezzlement. New York: Free Press.

David-Barrett, L., \& Okamura, K. (2013). The Transparency Paradox: Why do Corrupt Countries Join EITI? European Research Centre for Anti-Corruption and State-Building Working Paper No. 38.

Davis, J. (1998). Access to and Transmission of Information: Position of the Media. In V. Deckmyn \& I. Thomson (Eds.), Openness and transparency in the European Union (pp. 121-6). Maastricht: European Inst. of Public Administration.

den Boer, M. G. W. (1998). Steamy windows: Transparency and openness in justice and home affairs. In V. Deckmyn \& I. Thomson (Eds.), Openness and Transparency in the European Union (pp. 91-105). Maastricht: European Inst. of Public Administration.

Eigen, P. (2006). Fighting corruption in a global economy: Transparency initiatives in the oil and gas industry. Hous. J. Int'l L., 29, 327.

Eijffinger, S. C. W., \& Geraats, P. M. (2006). How transparent are central banks? European Journal of Political Economy, 22(1), 1-21.

Eisenberg, E. M. (2006). Strategic ambiguities: Essays on communication, organization, and identity. Thousand Oaks: Sage.

EITI. (2016a). History of the EITI | Extractive Industries Transparency Initiative. Retrieved July 13, 2017, from https://eiti.org/history

EITI. (2016b). Nigeria | Extractive Industries Transparency Initiative. Retrieved July 19, 2017, from https://eiti.org/nigeria

EITI. (2016c). The EITI standard. Oslo: EITI International Secretariat.

Etzioni, A. (2010). Is Transparency the Best Disinfectant? Journal of Political Philosophy, 18(4), 389-404.

Fenster, M. (2005). The opacity of transparency. Iowa L. Rev., 91, 885.

Fenster, M. (2015). Transparency in search of a theory. European Journal of Social Theory, $18(2), 150-167$.

Finel, B. I., \& Lord, K. M. (1999). The surprising logic of transparency. International Studies Quarterly, 43(2), 315-339.

Flyverbom, M., Christensen, L. T., \& Hanson, H. K. (2011). Disentangling the powertransparency nexus. In First Global Conference on Transparency Research, Rutgers University, Newark, NJ (pp. 19-20). 
Goldwyn, D. (2006). Nigeria's Struggle With Corruption - Testimony Before The US Congress Subcommittee on Africa, Global Human Rights and International Operations. Retrieved July 15, 2017, from http://commdocs.house.gov/committees/intlrel/hfa27648.000/hfa27648_0f.htm

Goxi, (2010). Jonathan Appointed NEITI Board Illegally. Retrieved July 18, 2017, from http://goxi.org/profiles/blogs/jonathan-appointed-neiti-board

Hansen, H. K., Christensen, L. T., Flyverbom, M., Hansen, H. K., Christensen, L. T., \& Flyverbom, M. (2015). Introduction: Logics of transparency in late modernity. European Journal of Social Theory, 18(2), 117-131.

Haufler, V. (2010). Disclosure as Governance: The Extractive Industries Transparency Initiative and Resource Management in the Developing World. Global Environmental Politics, 10(3), 53-73.

Haynes, K. (2010). Other lives in accounting: Critical reflections on oral history methodology in action. The Contours of Critical Accounting, 21(3), 221-231.

Hood, C. (2006). Transparency in historical perspective. In C. Hood \& D. Heald (Eds.), Transparency: The key to better governance? (pp. 3-23). Oxford: Oxford University Press.

Hood, C. (2007). What happens when transparency meets blame-avoidance? Public Management Review, 9(2), 191-210.

International Accounting Standards Board. (2010). The Conceptual Framework for Financial Reporting 2010. IFRS.

Jack, S. L., \& Anderson, A. R. (2002). The effects of embeddedness on the entrepreneurial process. Journal of Business Venturing, 17(5), 467-487.

Jack, S., Moult, S., Anderson, A. R., \& Dodd, S. (2010). An entrepreneurial network evolving: Patterns of change. International Small Business Journal, 28(4), 315-337.

Johnson, P. E., Grazioli, S., \& Jamal, K. (1993). Fraud detection: Intentionality and deception in cognition. Accounting, Organizations and Society, 18(5), 467-488.

Johnson, P. E., Grazioli, S., Jamal, K., \& Berryman, R. G. (2001). Detecting deception: adversarial problem solving in a low base-rate world. Cognitive Science, 25(3), 355-392.

Kasekende, E., Abuka, C., \& Sarr, M. (2016). Extractive industries and corruption: Investigating the effectiveness of EITI as a scrutiny mechanism. Resources Policy, 48, 117 128.

Klintman, M., \& Boström, M. (2008). Transparency through labelling? Layers of visibility in environmental risk management. In C. Garsten \& M. Montoya (Eds.), Transparency in a New Global Order. Unveiling Organizational Visions (pp. 178-197). Cheltenham: Edward Elgar Publishing.

Mattelart, A., \& Mattelart, M. (1992). Rethinking media theory: Signposts and new directions. Minneapolis: University of Minnesota Press. 
Maines, L. A., \& Wahlen, J. M. (2006). The Nature of Accounting Information Reliability: Inferences from Archival and Experimental Research. Accounting Horizons, 20(4), 399-425.

McPhail, K., Nyamori, R. O., \& Taylor, S. (2016). Escaping accountability: a case of Australia's asylum seeker policy. Accounting, Auditing \& Accountability Journal, 29(6), 947-984.

Meijer, A. (2013). Understanding the complex dynamics of transparency. Public Administration Review, 73(3), 429-439.

Muller, M. (2011). Turning the curse into a blessing: A convenient Illusion. Lessons from the Nigerian EITI process. In J. Runge \& J. Shikwati (Eds.), Geological Resources and Good Governance in Sub-Saharan Africa: Holistic Approaches to Transparency and Sustainable Development in the Extractive Sector (pp. 69-88). Boca Raton, FL: CRC Press.

NEITI. (2016). Brief History of NEITI. Retrieved July 13, 2017, from http://www.neiti.gov.ng/index.php/aboutus/brief-history-of-neiti

Ocheni, S., \& Nwankwo, B. C. (2012). The effectiveness of anti-corruption agencies in enhancing good governance and sustainable developmental growth in Africa: The Nigeria paradox Under Obasanjo Administration, 2003-2007. Canadian Social Science, 8(3), 16.

Öge, K. (2016). Which transparency matters? Compliance with anti-corruption efforts in extractive industries. Resources Policy, 49, 41-50.

Öge, K. (2017). Transparent autocracies: The Extractive Industries Transparency Initiative (EITI) and civil society in authoritarian states. The Extractive Industries and Society. https://doi.org/10.1016/j.exis.2016.12.010

Olayinka, C. (2016). Nigeria: Coalition Lauds Buhari On NEITI Board, Faults Nomination Process. Retrieved July 18, 2017, from http://allafrica.com/stories/201604280098.html

Onwuemenyi, O. (2012,). Fuel subsidy scandal and NEITI audit reports. Vanguard Newspaper August 7, 2012 Retrieved July 18, 2017, from http://www.vanguardngr.com/2012/08/fuel-subsidy-scandal-and-neiti-audit-reports/

Reporters Without Boarders. (2017). 2017 World Press Freedom Index. Retrieved July 21, 2017, from https://rsf.org/en/ranking

Rezaee, Z. (2005). Causes, consequences, and deterence of financial statement fraud. Critical Perspectives on Accounting, 16(3), 277-298.

Robinson, W. S. (1951). The logical structure of analytic induction. American Sociological Review, 16(6), 812-818.

Rotimi, O., \& Abdul-Azeez, A. A. (2013). Revenue Generation and Transparency in Nigeria Oil and Gas Industry:[Position of Nigeria Extractive Industries Transparency Initiative (Neiti)]. Research Journal of Finance and Accounting, 4(6), 99-114.

Shaxson, N. (2009). Nigeria's Extractive Industries Transparency Initiative: Just a Glorious Audit? London: Chatham House (Royal Institute of International Affairs). 
Sikka, P., \& Willmott, H. (2010). The dark side of transfer pricing: Its role in tax avoidance and wealth retentiveness. Critical Perspectives on Accounting, 21(4), 342-356.

Sovacool, B. K., \& Andrews, N. (2015). Does transparency matter? Evaluating the governance impacts of the Extractive Industries Transparency Initiative (EITI) in Azerbaijan and Liberia. Resources Policy, 45, 183-192.

Sovacool, B. K., Walter, G., Van de Graaf, T., \& Andrews, N. (2016). Energy governance, transnational rules, and the resource curse: exploring the effectiveness of the Extractive Industries Transparency Initiative (EITI). World Development, 83, 179-192.

Strathern, M. (2000). The tyranny of transparency. British Educational Research Journal, 26(3), 309-321.

Thedvall, R. (2008). Transparency at work: The production of indicators for EU employment policy. In C. Garsten \& M. Montoya (Eds.), Transparency in a new global order (pp. 143160). Cheltenham: Edward Elgar Publishing.

Transparency International. (2017). Corruption Perceptions Index 2016. Berlin: Transparency International.

Tsoukas, H. (1997). The tyranny of light: The temptations and the paradoxes of the information society. Futures, 29(9), 827-843.

Udo, B. (2010). Transparency agency commences self-cleansing | Nigeria Content Online. Retrieved July 18, 2017, from http://nigeriang.com/money/transparency-agency-commencesself-cleansing-2/4874/

Udo, B. (2015). Unrest in NEITI over dissolution of govt boards by Buhari. Premium Times Newspaper, July 23, 2015. Retrieved July 18, 2017, from

http://www.premiumtimesng.com/business/187124-unrest-in-neiti-over-dissolution-of-govtboards-by-buhari.html

United Nations Development Programme. (2016). Human Development Report 2016. New York, NY, US: United Nations Develpment Programme.

U.S. Energy Information Administration. (2016). Country Analysis Brief: Nigeria. Washington D.C.: U.S Energy Information Administration

Wehmeier, S., \& Raaz, O. (2012). Transparency matters: The concept of organizational transparency in the academic discourse. Public Relations Inquiry, 1(3), 337-366.

Wells, J. T. (2002). Occupational Fraud: The Audit as Deterrent. Journal of Accountancy, 193(4), 24-28.

World Bank. (2008). Implementing the Extractive Industries Transparency Initiative: Applying Early Lessons from the Field. Washington DC: World Bank. 
Figure 1: The Analytic Process

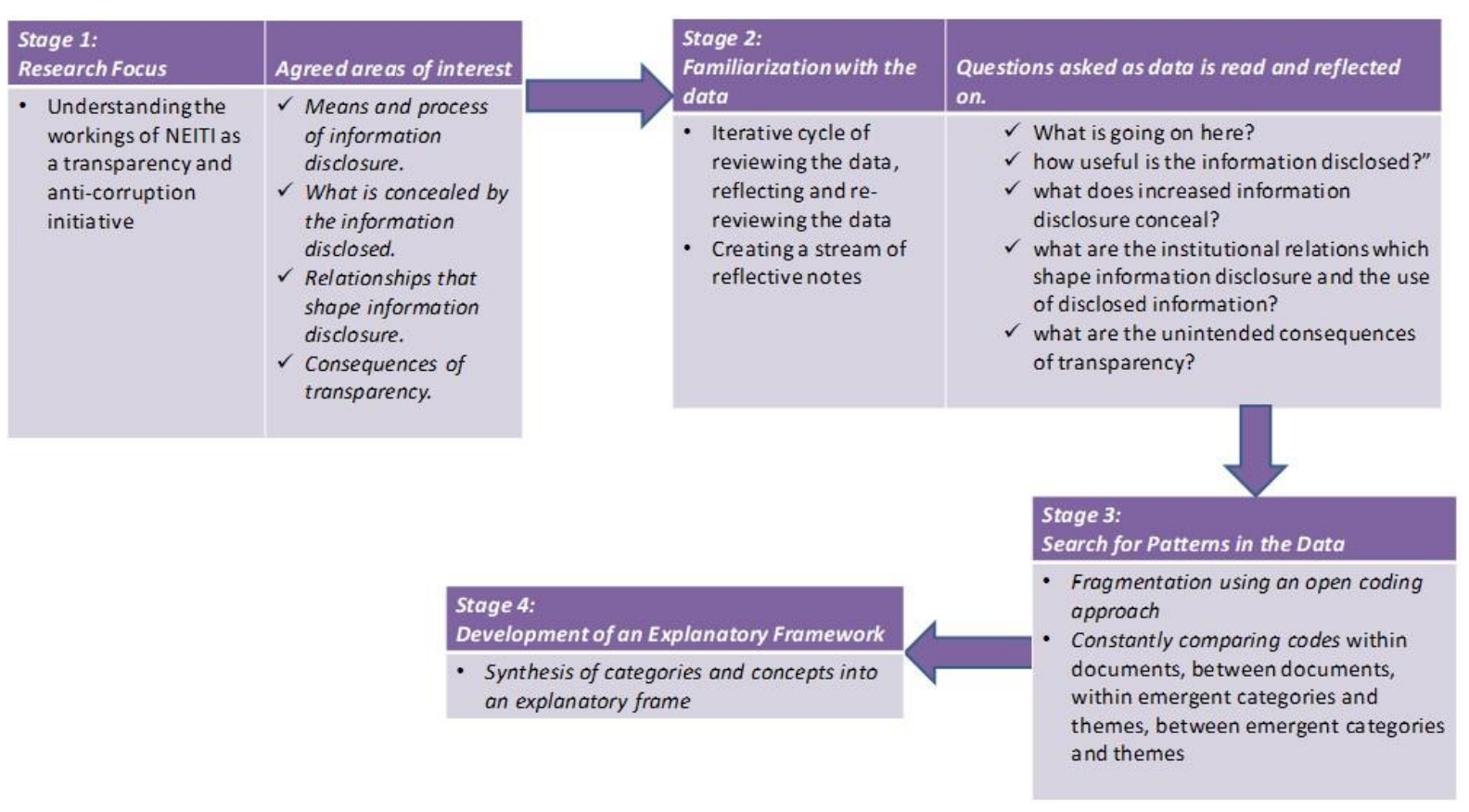


Figure 2: NEITI Transparency Process

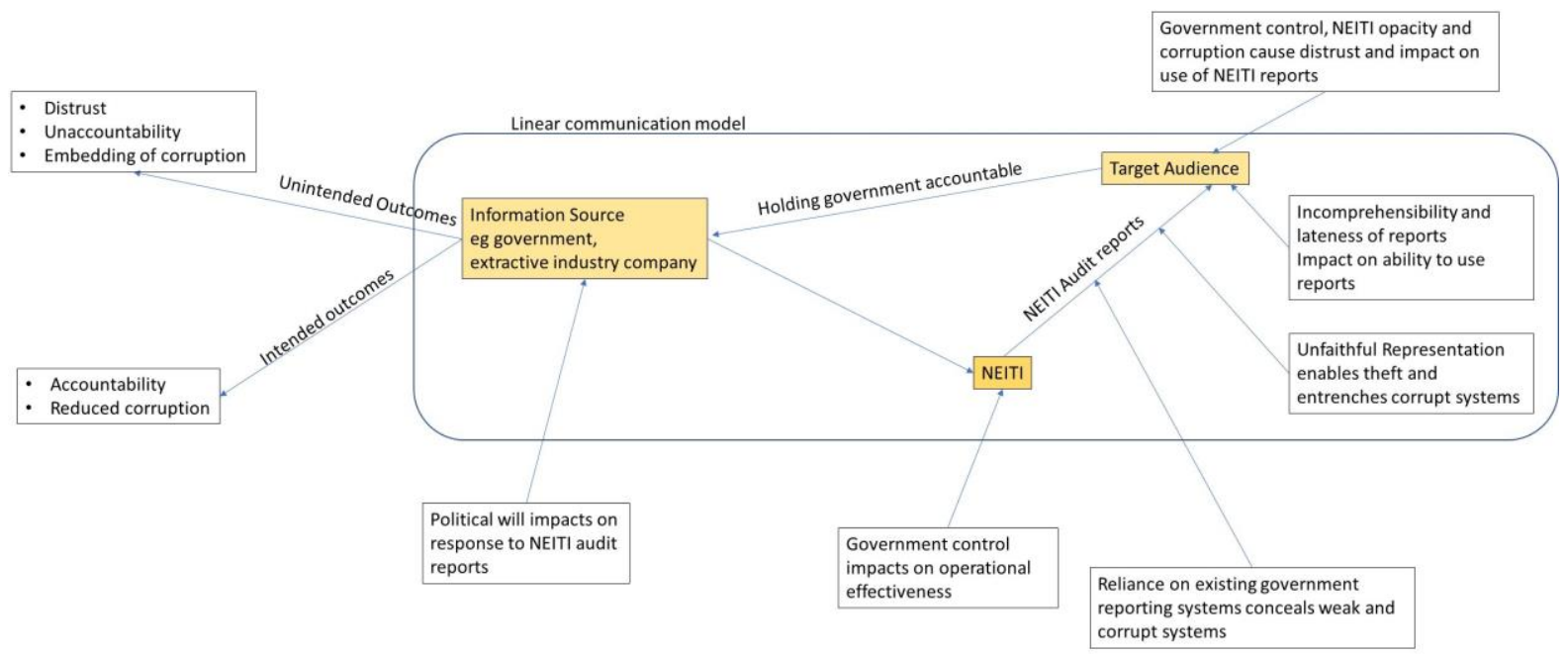


Table 1: NEIT Reporting Practice

\begin{tabular}{|l|l|l|}
\hline Period Report Covers & $\begin{array}{l}\text { Date of } \\
\text { Publication }\end{array}$ & Lag \\
\hline 2015 & Dec 2017 & 2 years \\
\hline 2014 & Dec 2016 & 2 years \\
\hline 2013 & Sept 2015 & 2 years \\
\hline 2012 & March 2015 & 3 years \\
\hline $2009-2011$ & Dec 2012 & $1-3$ year \\
\hline $2006-2008$ & July 2011 & $3-5$ years \\
\hline 2005 & Oct 2008 & 3 years \\
\hline $1999-2004$ & Aug 2006 & $\begin{array}{l}\text { Produced } \\
\text { retrospectively }\end{array}$ \\
\hline
\end{tabular}


Table 2: Appendix 3

\begin{tabular}{|c|c|}
\hline Actor & Description \\
\hline Global EITI & $\begin{array}{l}\text { The Global EITI evaluates countries' performance } \\
\text { in reaching the requirements of the EITI } \\
\text { Standard, rewarding or sanctioning countries' as } \\
\text { appropriate. It has very little direct control over } \\
\text { the operations of the national implementing } \\
\text { agencies i.e. NEITI in our case. }\end{array}$ \\
\hline NEITI & $\begin{array}{l}\text { This is the Nigerian organisation which } \\
\text { implements the EITI framework in Nigeria. It is } \\
\text { set up in accordance with the NEITI Act. }\end{array}$ \\
\hline $\begin{array}{l}\text { NEITI National Stakeholder Working } \\
\text { Group (NSWG) }\end{array}$ & $\begin{array}{l}\text { The NSWG is the governing body of NEITI. It } \\
\text { acts much like a Board of Directors and its roles } \\
\text { include: formulating policies, programmes and } \\
\text { strategies; approving budgets and work-plans; } \\
\text { overseeing the operations of the organisation; } \\
\text { commissioning and approving NEITI audits. Its } \\
\text { members are appointed by the Nigerian President } \\
\text { in accordance with the NEITI Act. }\end{array}$ \\
\hline NEITI Chairperson & $\begin{array}{l}\text { The Chair of the NEITI NSWG. The Chair much } \\
\text { like the Chair of a Board of Directors has no } \\
\text { executive powers. }\end{array}$ \\
\hline NEITI Executive Secretary & $\begin{array}{l}\text { The Chief Executive Officer of NEITI. The } \\
\text { Executive Secretary is appointed by the Nigerian } \\
\text { President and serves as Secretary to the NSWG. }\end{array}$ \\
\hline Civil Society Organisations & $\begin{array}{l}\text { Civil society organisations work with NEITI as } \\
\text { stakeholders in the governance of the oil and gas } \\
\text { industry in Nigeria. The NEITI Act requires one } \\
\text { member of the NSWG to be a representative of } \\
\text { civil society. }\end{array}$ \\
\hline $\begin{array}{l}\text { Nigerian National Petroleum } \\
\text { Corporation (NNPC) }\end{array}$ & $\begin{array}{l}\text { NNPC is the National oil company. It manages } \\
\text { the Nigerian government's stake in all joint } \\
\text { venture production agreements in the oil and gas } \\
\text { industry. It receives money from crude oil sales } \\
\text { on behalf of the Nigerian government. }\end{array}$ \\
\hline $\begin{array}{l}\text { Directorate of Petroleum Resources } \\
\text { (DPR) }\end{array}$ & $\begin{array}{l}\text { DPR is statutorily responsible for ensuring } \\
\text { compliance with petroleum laws, regulations and } \\
\text { guidelines in the Oil and Gas Industry. In this } \\
\text { capacity it regulates the activities of NNPC and } \\
\text { other companies operating in the oil and gas } \\
\text { industry in Nigeria. }\end{array}$ \\
\hline Ministry of Finance & $\begin{array}{l}\text { The Ministry of Finance is the government } \\
\text { ministry that manages the finances of the } \\
\text { Nigerian government. Its role includes managing, } \\
\text { controlling and monitoring oil and gas revenues } \\
\text { and expenditures. }\end{array}$ \\
\hline Central Bank of Nigeria $(\mathrm{CBN})$ & $\begin{array}{l}\text { CBN is the reserve bank and monetary authority } \\
\text { in Nigeria. It manages the countries external }\end{array}$ \\
\hline
\end{tabular}




\begin{tabular}{|c|c|}
\hline & $\begin{array}{l}\text { reserve. Oil revenues are meant to be remitted } \\
\text { from NNPC to the CBN. }\end{array}$ \\
\hline Nigerian President & $\begin{array}{l}\text { The Nigerian President is the head of state and } \\
\text { head of government of Nigeria. The NEITI Act } \\
\text { gives the President the power to appoint members } \\
\text { of the NSWG and the Executive Secretary. Since } \\
\text { inception of NEITI in 2004, Nigeria has been } \\
\text { ruled by four Presidents. } \\
\text { - President Olusegun Obasanjo (1999 - 2007): } \\
\text { Brought the EITI and NEITI to Nigeria as } \\
\text { part of his anti-corruption reforms. } \\
\text { Supported NEITI for most part of his tenure. } \\
\text { President Musa Yaradua (2007 - 2010): } \\
\text { Succeeded President Obasanjo. Was not } \\
\text { really interested in anti-corruption reforms } \\
\text { so did not give NEITI much support. } \\
\text { President Goodluck Johnathan (2010 - } \\
\text { 2015): Succeeded President Yaradua. Was } \\
\text { not interested in anti-corruption reforms and } \\
\text { so did not give NEITI much support. } \\
\text { President Muhammadu Buhari (2015 - } \\
\text { present): Succeeded President Johnathan. } \\
\text { President Buhari's major campaign promise } \\
\text { was to fight corruption in Nigeria. He has } \\
\text { given support to NEITI since coming into } \\
\text { office. }\end{array}$ \\
\hline NEITI target audience & $\begin{array}{l}\text { NEITI target audience include the government, } \\
\text { parliamentarians, civil society, companies, the } \\
\text { media and the Nigerian public. This target } \\
\text { audience is meant to use NEITI audit reports to } \\
\text { hold the government accountable. }\end{array}$ \\
\hline Extractive industry companies & $\begin{array}{l}\text { These are companies who participate in the oil } \\
\text { and gas industry in Nigeria. These include } \\
\text { multinationals like Royal Dutch Shell, Agip, } \\
\text { ExxonMobil, Total S.A, Chevron all of whom } \\
\text { have joint venture operations with the Nigerian } \\
\text { government (NNPC). It also includes indigenous } \\
\text { oil companies. }\end{array}$ \\
\hline
\end{tabular}


Table 3: Appendix 4

\begin{tabular}{|c|c|}
\hline In Text Reference & Data Source \\
\hline Channels TV Interview A & $\begin{array}{l}\text { Hard Copy: Waziri Adio Gives Reasons For Late Publishing Of } \\
\text { NEITI's Report, Channels TV interview with NEITI Executive } \\
\text { Secretary. }\end{array}$ \\
\hline EITI Guidance Note 12 & Guidance Note 12 on Summary EITI Report, EITI \\
\hline $\begin{array}{l}\text { Presentation by NEITI } \\
\text { Executive Secretary to IMF } \\
\text { Mission on } 21 \text { March } 2012\end{array}$ & $\begin{array}{l}\text { NEITI: The Prospects, Issues and Challenges, Presentation by } \\
\text { NEITI Executive Secretary to IMF Mission on } 21 \text { March } 2012\end{array}$ \\
\hline Onwuemenyi (2012) & $\begin{array}{l}\text { Fuel subsidy scandal and NEITI audit reports. Vanguard } \\
\text { Newspaper August 7, } 2012 .\end{array}$ \\
\hline IASB (2010) & $\begin{array}{l}\text { International Accounting Standards Board. (2010). The } \\
\text { Conceptual Framework for Financial Reporting 2010. IFRS. }\end{array}$ \\
\hline $\begin{array}{l}\text { NEITI } 2016 \text { oil and gas audit } \\
\text { report }\end{array}$ & NEITI 2016 oil and gas audit report \\
\hline $\begin{array}{l}\text { US Embassy Cables Leak, } \\
\text { Wikileaks Cable } \\
\text { 09LAGOS438_a }\end{array}$ & $\begin{array}{l}\text { Fundamentals of Illegal Oil Bunkering In Nigeria, Cable from } \\
\text { US Consulate in Lagos, Nigeria. } 18 \text { Nov } 2009 \text { obtained from } \\
\text { WikiLeaks }\end{array}$ \\
\hline NEITI Report (2010) & 10 years of NEITI reports : what have we learnt? NEITI \\
\hline EITI (2016c) & The EITI standard. Oslo: EITI International Secretariat. \\
\hline PwC (2015) & $\begin{array}{l}\text { Investigative Forensic Audit into the Allegations of Unremitted } \\
\text { Funds into the Federation Accounts by the NNPC, } \\
\text { PricewaterhouseCoopers, February } 2015 .\end{array}$ \\
\hline $\begin{array}{l}\text { NEITI } 2013 \text { Oil and Gas Audit } \\
\text { Report }\end{array}$ & NEITI 2013 Oil and Gas Audit Report \\
\hline Shaxson (2009) & $\begin{array}{l}\text { Shaxson, N. (2009). Nigeria's Extractive Industries } \\
\text { Transparency Initiative: Just a Glorious Audit? London: } \\
\text { Chatham House (Royal Institute of International Affairs) }\end{array}$ \\
\hline Channels TV Interview B & $\begin{array}{l}\text { Hard Copy: More Still Need To Be Done On Transparency In } \\
\text { The Extractive Industry - Waziri Adio, Channels TV interview } \\
\text { with NEITI Executive Secretary }\end{array}$ \\
\hline $\begin{array}{l}\text { News Agency of Nigeria TV } \\
\text { Interview }\end{array}$ & $\begin{array}{l}\text { NNPC can not refute our claims, says NEITI, News Agency of } \\
\text { Nigeria TV interview with NEITI Executive Secretary }\end{array}$ \\
\hline Udo (2015) & $\begin{array}{l}\text { Transparency agency commences self-cleansing | Nigeria } \\
\text { Content Online. Available at } \\
\text { http://nigeriang.com/money/transparency-agency-commences- } \\
\text { self-cleansing-2/4874/ }\end{array}$ \\
\hline Abutudu and Garuba (2010) & $\begin{array}{l}\text { Natural Resource Governance and EITI Implementation in } \\
\text { Nigeria. Nordiska Afrikainstitutet. }\end{array}$ \\
\hline Olayinka (2016) & $\begin{array}{l}\text { Nigeria: Coalition Lauds Buhari On NEITI Board, Faults } \\
\text { Nomination Process. Available at } \\
\text { http://allafrica.com/stories/201604280098.html }\end{array}$ \\
\hline
\end{tabular}




\begin{tabular}{|c|c|}
\hline Muller (2011) & $\begin{array}{l}\text { Turning the curse into a blessing: A convenient Illusion. } \\
\text { Lessons from the Nigerian EITI process. In J. Runge \& J. } \\
\text { Shikwati (Eds.), Geological Resources and Good Governance } \\
\text { in Sub-Saharan Africa: Holistic Approaches to Transparency } \\
\text { and Sustainable Development in the Extractive Sector (pp. 69- } \\
\text { 88). Boca Raton, FL: CRC Press }\end{array}$ \\
\hline Speech by Dauda Garuba & $\begin{array}{l}\text { Speech by Dauda Garuba at the Public Presentation of a Book } \\
\text { on Performance Assessment of the NEITI at Bolton White } \\
\text { Hotel Abuja, } 30 \text { September } 2010\end{array}$ \\
\hline
\end{tabular}


Table 4: Appendix 5

\begin{tabular}{|c|c|c|}
\hline Document Type & Description & $\begin{array}{l}\text { Number of } \\
\text { Reports }\end{array}$ \\
\hline $\begin{array}{l}\text { NEITI Oil and Gas } \\
\text { Audit Reports }\end{array}$ & $\begin{array}{l}\text { Financial, Physical and Process Audit } \\
\text { Reports for the periods: } 1999-2004 \text {; } \\
\text { 2005; 2006-2008; 2009-2001; } \\
2012 ; 2013,2014,2015\end{array}$ & 8 \\
\hline NEITI Activity Report & $\begin{array}{l}\text { Activity Reports to EITI in 2012, } \\
2013,2014,2015,2016\end{array}$ & 5 \\
\hline NEITI Strategic Plan & Strategic planning document & 2 \\
\hline $\begin{array}{l}\text { NEITI } \\
\text { Communication } \\
\text { Strategy }\end{array}$ & $\begin{array}{l}\text { NEITI Communication strategy } \\
\text { document }\end{array}$ & 1 \\
\hline MSWG Membership & $\begin{array}{l}\text { MSWG Membership list: } 2008 \text { - } \\
\text { 2012; 2012 - 2015; } 2016\end{array}$ & 3 \\
\hline NEITI Act & Legislative enactment & 1 \\
\hline $\begin{array}{l}\text { NEITI Open Audit } \\
\text { Magazine }\end{array}$ & $\begin{array}{l}\text { NEITI magazine targeted at the } \\
\text { public: June } 2011 \text { - Feb } 2017\end{array}$ & 14 \\
\hline NEITI policy brief & $\begin{array}{l}\text { NEITI statements aimed at } \\
\text { contributing to and shaping national } \\
\text { policy }\end{array}$ & 3 \\
\hline NEITI Newsletter & $\begin{array}{l}\text { NEITI newsletter to staff: January } \\
2016 \text { - May } 2017\end{array}$ & 10 \\
\hline NEITI Workplan & $\begin{array}{l}\text { NEITI annual workplans approved by } \\
\text { MSWG: } 2009 \text { - } 2018\end{array}$ & 12 \\
\hline $\begin{array}{l}\text { NEITI Quarterly } \\
\text { Review }\end{array}$ & Quarterly summary report & 7 \\
\hline $\begin{array}{l}\text { NEITI Evaluation } \\
\text { Report }\end{array}$ & $\begin{array}{l}\text { Evaluation of pilot assessment of } \\
\text { Beneficial Ownership disclosure }\end{array}$ & 1 \\
\hline $\begin{array}{l}\text { NEITI Occasional } \\
\text { Papers }\end{array}$ & $\begin{array}{l}\text { NEITI papers aimed at shaping policy } \\
\text { debate }\end{array}$ & 2 \\
\hline $\begin{array}{l}\text { Civil Society in NEITI } \\
\text { Process }\end{array}$ & $\begin{array}{l}\text { Report on NEITI engagement with } \\
\text { civil society }\end{array}$ & 1 \\
\hline $\begin{array}{l}\text { Civil Society } \\
\text { publications }\end{array}$ & $\begin{array}{l}\text { Reports, blogs and other publications } \\
\text { on NEITI and its operations by civil } \\
\text { society organisations including } \\
\text { Chatham House. }\end{array}$ & 20 \\
\hline $\begin{array}{l}10 \text { Years of NEITI } \\
\text { report }\end{array}$ & $\begin{array}{l}\text { NEITI reflections on lessons learnt } \\
\text { from } 10 \text { years of reporting }\end{array}$ & 2 \\
\hline NEITI HR Documents & $\begin{array}{l}\text { NEITI staff directory, organisational } \\
\text { structure and human resources } \\
\text { manual. }\end{array}$ & 3 \\
\hline NEITI Press Releases & NEITI press releases on NEITI website & 225 \\
\hline $\begin{array}{l}\text { KPMG and PwC } \\
\text { reports }\end{array}$ & $\begin{array}{l}\text { Reports of forensic audits of NNPC } \\
\text { carried out by KPMG and PwC }\end{array}$ & 2 \\
\hline $\begin{array}{l}\text { Videos on NEITI } \\
\text { website }\end{array}$ & $\begin{array}{l}\text { Videos of interviews and } \\
\text { presentations made by the EITI } \\
\text { Executive Secretary }\end{array}$ & 8 \\
\hline Other Videos & $\begin{array}{l}\text { Videos aired on Nigerian Television. } \\
\text { These include interviews with the }\end{array}$ & 45 \\
\hline
\end{tabular}




\begin{tabular}{|l|l|c|}
\hline & $\begin{array}{l}\text { NEITI Executive Secretary and other } \\
\text { NEITI officials, interviews with } \\
\text { government officials which discuss } \\
\text { NEITI, reports on NEITI and its work, } \\
\text { etc. }\end{array}$ & \\
\hline Wikileaks & $\begin{array}{l}\text { US Embassy in Nigeria cable } \\
\text { communication leaked by Wikileaks. } \\
\text { These are cables sent from the US } \\
\text { Mission in Lagos and Embassy in } \\
\text { Abjua to the US State Department } \\
\text { which discuss NEITI and the oil and } \\
\text { gas sector in Nigeria. Initial search } \\
\text { yielded 2,561 results of which 465 } \\
\text { were deemed relevant. }\end{array}$ & \\
\hline Nigerian and Global & $\begin{array}{l}\text { News reports about NEITI in the } \\
\text { Nigerian and global press obtained } \\
\text { new the Nexis database. Initial } \\
\text { search yielded 4,578 results of which } \\
\text { 2,425 were deemed relevant. }\end{array}$ & \\
\hline EITI Standards and revisions thereof. & \\
\hline EITI Standard & $\begin{array}{l}\text { Guidance notes on aspects of the } \\
\text { EITI Standard and other related } \\
\text { issues published by EITI }\end{array}$ & 2,425 \\
\hline EITI Guidance Notes website country page for Nigeria & 25 \\
\hline EITI Country page & Total & 3,293 \\
\hline & & \\
\hline
\end{tabular}

